\title{
LIVING IN A LAND OF EPITHETS: ANONYMITY IN JUDGES 19-21*
}

\author{
Don Michael Hudson
}

Colorado Christian University

Judges is about loss: a loss of the individual which leads to a loss of the tribe, and, if circumstances remain unchecked, a loss of the nation. The narrative chronicles and reflects a rapidly disintegrating society that was oblivious to a gradually disappearing God. The God of Judges 1 differs greatly from the God of Judges 20 . The God of Judges 1 stipulates that Judah shall go up first to inherit the land (v. 2) and then proceeds to defeat Judah's enemies. In like fashion, the God of ch. 20 answers Israel's question of who should proceed first against Benjamin: 'Judah shall go up first' (v. 18). Only this time, Judah is defeated. At best, the God of Judges 20 is ambiguous; at worst, he is absent.

This is why Judges 19-21, though replete with many difficulties, is an integral part of the whole narrative. This section exhibits the nadir of the unraveling of a society and a narrative. Narrative does as society does. As one example among many, the narrator employs the concept of anonymity as a major literary technique to display the loss of familial, tribal and national wholeness. Anonymity in Judges 19-21 symbolizes and epitomizes the gradual, downward spiraling disintegration and dehumanization that is occurring increasingly throughout the narrative until it reaches radical anarchy in chs. 17-21.

\section{A Literary Framework for Understanding Anonymity in Judges 19-21}

In a recent article, Cheryl Exum agrees with scholars who would argue that the framework of Judges is difficult and obfuscated; and yet, she

* Special thanks to Peter Miscall, Tremper Longman, III, and Moisés Silva. 
asserts that these very textual anomalies are utilized by the narrator to portray an ideology of dissolution. ${ }^{1}$ Exum's reading reinterprets philological and historical understandings in a way that does not ignore the difficulties of the text but calls attention to the fact that these particular narrative obscurities and framework dissimilarities are intentional on the part of the narrator. She makes the important point that the deuteronomistic framework of apostasy, punishment, cry for help, and deliverance presented in the beginning is merely a uniform paradigm guiding the reader to expect the execution and development of that paradigm.

Although we are led to expect a consistent and regular pattern, what happens is that the framework itself breaks down. Rather than attributing the lack of consistency in the framework pattern to careless redaction, I take it as a sign of further dissolution. The political and moral instability depicted in Judges is reflected in the textual instability. The framework deconstructs itself, so to speak, and the cycle of apostasy and deliverance becomes increasingly murky. ${ }^{2}$

Mieke Bal has also noted that Judges is a unique literary work in that its incoherence leads to its coherence; its obscurities lead to a reading that views incoherence and dissymmetry as contributing to the understanding of Judges. ${ }^{3}$ Judges is not primarily an Israelite historiography as most interpreters have proposed. Much more than that, it is a narrative written in a downward spiral revealing Israel's failure to serve Yhwh only and the consequences of such disobedience with the result that, in the end, Israel, rather than the 'alien' nations, begins to dismember itself into oblivion.

The narrator's execution of characterization treads this same downward path. The named characters in the beginning of Judges are, using Northrup Frye's fictional categories, high-mimetic heroes who in degree are superior to subsequent characters but eventually succumb to the inevitable result of Judges-self-destruction. ${ }^{4}$ Judah, Simeon, Achsah,

1. 'The Centre Cannot Hold: Thematic and Textual Instabilities in Judges', $C B Q$ 52 (1990), pp. 410-12.

2. 'The Centre Cannot Hold', p. 412.

3. Death and Dissymmetry (Chicago: The University of Chicago Press, 1988), pp. 9-21.

4. Northrup Frye's modes of fiction are also helpful in understanding the digressive nature of the Judges narrative. Frye places all modes of fiction within the continuum of myth (the hero is superior in kind both to other men and to the environment'), romance ('superior in degree to other men and to his environment'), 
Othniel, Ehud and Deborah fall into this mode of representation. The heroes succeed, but the book of Judges beginning with ch. 1 describes the futility of every victory. Judges appears to be a book that constantly details the hero's eventual frustration by his or her environment, that is, the alien nations. The narrative then in a loose manner digresses to stories of low-mimetic, where the heroes are superior neither to other people or to their environment. Gideon is a faithless, faltering warrior who eventually leads the Israelites into idolatry. The ruthless Abimelech uses savagery to advance his shameful position but is ultimately brought down by a nameless woman. Jephthah the negotiator appropriates his nameless daughter to insure his status as a gibbôr. Samson, the son of a nameless woman, rather than destroying the Philistines, deliberately destroys himself. ${ }^{5}$ Just as the ineffective tribe of Benjamin, the ambiguous Ehud and the feeble Barak foreshadow the low-mimetic major characters, Gideon, Abimelech, Jephthah and Samson foreshadow the cast of characters in chs. 17-21. ${ }^{6}$ The Judges narrative concludes the cyclical digression of characterization and plot-line in the ironic mode of Judges 17-21. In this pericope two characters are named (Micah and Phinehas) and, as will be discussed later, all the other characters are anonymous. This use of anonymity brings the reader to the end of the narrator's descending characterization. As the plot unravels, so does the characterization.

The characters and events fall into Frye's criteria for narrative that is irony-both tragic and comic. In ironic tragedy the hero is isolated from his or her society - he or she can be a victim or agent in society; the narrator writes with objectivity and represses moral statements; the reader looks down on the characters and their actions; and the narrative

high mimetic ('superior in degree to other men but not to his natural environment, the hero is a leader'), low mimetic ('superior neither to other men nor to his environment, the hero is one of us'), and ironic ('inferior in power or intelligence to ourselves, so that we have a sense of looking down on a scene of bondage, frustration, or absurdity'). See The Anatomy of Criticism (Princeton: Princeton University Press, 1957), pp. 33-34. Interestingly, Frye notes that these modes of fiction occur cyclically in history, digressing from myth to irony and then progressing back to myth (p. 52).

5. See M. Bal, 'Delilah Decomposed: Samson's Talking Cure and the Rhetoric of Subjectivity', in Lethal Love: Feminist Literary Readings of Biblical Stories (Bloomington: Indiana University Press, 1987), pp. 37-67.

6. Frye notes two interesting details about low-mimetic tragedy: the narrative evokes and communicates pity and fear rather than absorbing these emotions, and there is a growing sense of "inarticulateness" on the part of the victim (Anatomy of Criticism, pp. 38-39). 
communicates a mood of futility, absurdity and arbitrariness. ${ }^{7}$ Understanding ironic comedy discloses three other issues relevant to the discussion: the narrative communicates a savage world that inflicts pain on the victim; integral to the plot-line is the scapegoat ritual usually centered around mob violence; and the violence of the narrative is symbolic of the society's "viciousness' rather than the individual's. ${ }^{8}$ These categories of ironic fiction are surprisingly similar to much of the way the narrator represents the characters and events in Judges 19-21.

A comparison of the introduction and conclusion of Judges further reveals in a dramatic way the disintegrating modes of narrative structure and characterization leading to the absolute loss of identity reflected in anonymity. ${ }^{9}$ One interpretive problem in the introduction illustrates the interrelatedness of the two pericopes: the two different statements in ch. 1 that Jerusalem was taken by Judah (1.8) and in (1.21) that Benjamin failed to drive the Jebusites from Jerusalem. In the past, interpreters would use this supposed contradiction as an indicator of various redactors or different sources for this pericope. I want to propose, however, that these two statements foreshadow important realities to be developed as the plot-line digresses toward the conclusion: (1) already in ch. 1 the reader is left with the impossibility of pinpointing a succinct chronology for the book-this is also important for understanding the conclusion and how it relates to the whole; (2) as opposed to Joshua's almost ideal portrayal of inheriting the land, Judges begins immediately with ambiguous 'victories' and ends with an ambiguous 'victory'; (3) the narrator is beginning to allude to the difference and tension between Judah and Benjamin which will come to fruition in chs. 19-21; and (4) the narrator

7. Anatomy of Criticism, pp. 40-43.

8. Anatomy of Criticism, pp. 45-49. 'The next step is an ironic comedy addressed to the people who can realize that murderous violence is less an attack on a virtuous society by a malignant individual than a symptom of that society's own viciousness' (p. 48). Also see B. Simon, 'Tragic Drama and the Family: The Killing of Children and the Killing of Story-Telling', in S. Rimmon-Kenan (ed.), Discourse in Psychoanalysis and Literature (London: Methuen, 1987), pp. 152-175.

9. Exum comments that 'Judges begins with a double introduction, balanced by a double conclusion...' ('The Centre Cannot Hold', p. 413). She further states that the first narrative in the introduction deals with a military problem and the second with a religious problem. I would also like to follow up with the idea that chs. 17-21 are structured thematically opposite to the introduction, with the religious problem being in 17-18 and the military in 19-21. See also D.W. Gooding, 'The Composition of the Book of Judges', Eretz-Israel 16 (1982), pp. $70-79$. 
is 'setting up' the reader to expect that the major problem developing for Israel is that the alien nations are remaining in the land, whereas in chs. 19-21 Israel is its own worst enemy bent on dismembering and disinheriting itself.

Whatever the anomalies in the text of the introduction, the reader can readily observe both a dramatic comparison and contrast with the conclusion. Simply put, the introduction stages certain expectations for the plot development which are deconstructed, inverted and reversed vividly by the conclusion. ${ }^{10}$ Judges $17-21$ is a dialectic to the introduction without the possibility of any synthesis, wholeness or individual or national identity. ${ }^{11}$

The conclusion of Judges displays in a graphic manner the disintegration of a society in which the individuals 'do what is right in their own eyes'. Judges 19-21 is about a loss of leadership, a loss of boundaries, a loss of identity, a loss of names and naming. It is about chaos, disorder, obscurity and dismemberment. It is also about the obliteration of memory, lineage, genealogy. The characters proceed from women and men who regard the law and are successful in their exploits, to increasingly ambiguous characters who gradually 'lose sight' of a proper interpretation of the law, respect for relationship, and obedience of YHWH. When the reader reaches chs. 19-21, he or she observes nameless characters who have totally lost sight of what is right and what is wrong. With a few others I am suggesting that the narrator reflects this disintegration of society by slowly and methodically disintegrating his own patterns, stories and characters. By this I do not mean that these increasingly difficult readings are the result of careless writing or redaction, as most historical critics would aver. Instead this narrative is a product of a narrator who ingeniously portrays his message through the manipulation of his medium-not art for art's sake, but art for meaning's sake. ${ }^{12}$

10. S. Lasine, 'Guest and Host in Judges 19: Lot's Hospitality in an Inverted World', JSOT 29 (1984), pp. 37-59. S. Niditch, 'The "Sodomite" Theme in Judges 19-20: Family, Community, and Social Disintegration', $C B Q 44$ (1982), pp. 365-78. Lasine and Niditch both contrast and compare other biblical texts to Judg. 19-21 in an effort to exhibit that the narrative is an inversion and reversal.

11. The conclusion is far from any type of resolution for it resists conflation. Ironically, the conclusion is non-resolution or dissolution which hegs for resolution.

12. In my opinion the conclusion of Judges more than any other narrative in the Hebrew Bible comes the closest to resembling modern means of representing the 
The Significance and Function of Anonymity in Judges 19-21

As I have stated previously, my proposition is that anonymity is a literary technique applied by the narrator to epitomize familial, tribal and national deterioration. It is my contention that comprehending the significance and function of anonymity in Judges 19-21 will aid greatly in the understanding of this passage and the entire Judges narrative. As I commence this analysis of namelessness in chs. 19-21, I will assume a three-pronged methodology. Partly because of the lack of previous studies on anonymity and partly because of anonymity's contribution to the Judges 19-21 narrative, I will utilize a methodology of inversion to begin with. In other words, the first point of methodology will concentrate on extra-biblical meanings and functions of naming. Secondly, extra-textual (outside of Judg. 19-21) meanings and functions of naming and anonymity will be observed. And finally, we will examine the intratextual meanings and functions of anonymity in the Judges 19-21 pericope.

Though our modern day notion of naming does not carry as much weight as naming in the times and writing of the Hebrew Bible, we still place great stress on the concept of naming. There are popular songs that warn of the dangers of losing the name to the 'number'; persons are offended when another individual forgets his or her name; couples approach the precipice of divorce over the naming of their children, and the list could go on ad infinitum. Additionally, most of us would think it very strange to read a novel or watch a play or film that contained all nameless characters. Basically, it would be almost impossible to function on any relational level without the concept of naming.

Recent studies have emphasized the importance of naming and its implications for understanding the interrelatedness of language and relationship. ${ }^{13}$ Because of the scope of the subject and the fact that this

disintegration of meaning or naming. Some examples are The Story of $O$ by Pauline Reage, Samuel Beckett's play Endgame, Dadaism in art, and the modern existential novel.

13. J.V. Langmead Casserly, 'Event-Symbols and Myth Symbols', ATR 38 (1956), pp. 127-37 and 242-48; R. Clark, 'Presuppositions, Names and Description', Philosophical Quarterly 6 (1956), pp. 145-54; W. Percy, 'Naming and Being', The Personalist 41 (1960), pp. 148-58; J.R. Searle, 'Proper Names', Mind 71 (1962), pp. 230-35; P. Tournier, The Naming of Persons (trans. E. Hudson; New York: Harper \& Row, 1975). 
aspect of the methodology is farthest removed in relevance to the argument, the discussion will examine only two of the many sources concerned with naming. Walker Percy's article, 'Naming and Being', and Paul Tournier's book, The Naming of Persons will establish a foundation for understanding the significance of naming and will then be utilized as a dialectic for attempting to understand the phenomenon of anonymity.

Percy makes the point that naming is an essential concept that persons can study just as anyone can examine other phenomena, be it 'solar eclipses, glandular secretions, nuclear fusion, stimulus-response sequences'; and yet, truly and fully understanding naming 'is like trying to see a mirror while standing in front of it'. ${ }^{14}$ His major thesis takes semiotics to task for observing in naming nothing more than a conditioned response to any stimulus. ${ }^{15}$ In Percy's opinion, naming is more than response to stimuli or simple effects of causes; it involves understanding that naming 'names' something. In other words, naming is a mature recognition that giving a name or calling a name are processes of attributing meaning beyond the symbol. He asserts that this process of naming in this sense is the most essential step for human maturation. ${ }^{16}$ Furthermore, naming is an act of affirmation-'naming or symbolization may be defined as the affirmation of the thing as being what it is under the auspices of the symbol'. ${ }^{17}$ This act of 'affirmation' or naming must occur in the context of community and relationship (what a name means 'for you and for me'). Naming also 'orients' the person differently in his or her world-without naming the person merely

14. 'Naming and Being', pp. 148-50.

15. 'Naming and Being'. 'The semioticists are determined that meaning shall be a response, not utterly different from a solar eclipse or from dog salivation' (p. 149).

16. Percy illustrates these points with the analogy of a boy's understanding that a 'ball' is more than a 'round thing' (pp. 148-51).

17. 'Naming and Being', p. 151. Affirmation, however, does not conflate the symbol with the referrent. In Percy's words, 'As Allen Tate has pointed out, it was a general belief in the West until the seventeenth century that human beings do not know things directly, as do the angels, but only through the medium of something else: the symbol. In order that the strange bird [an unknown bird mentioned previously in the treatise] be known and affirmed, a pairing is required: The laying of symbol alongside thing. This pairing is the source of the scandal, for it occurs by the use of the copula "is". This is monstrous when understood as a real identity, but the difficulty disappears when it is understood as an intentional relation of identity' (p. 152). 
responds to other persons and stimuli. Without a name the person immediately enters the realm of objectification and inauthentic living, but an authentic person is one who is both a namer and a hearer of names, both an I and a Thou. ${ }^{18}$

Tournier speaks of the magnitude and implications of naming in relation to the naming of children. He emphasizes the fact that even before a child is born the naming of the infant involves the person of the child, its individual identity, and the respect due to him or her. ${ }^{19}$ According to Tournier, naming of the person brings two movements: separation and unity. 'What separates and distinguishes me from other people is the fact that I am called by my name, but what unites me with them is the very fact that they call me'. ${ }^{20}$ Tournier further notes a distinction between the manner in which Logos and Eros names. Logos names simply to classify, identify and define. Eros addresses the Thou by giving proper names. The difference can be illustrated in this way. I can call my dog a Labrador Retriever, and in so doing I am using a common name or a name that merely classifies intellectually. Or I can call my dog 'Tara', and in so doing I am expressing intimacy, connectedness, an I-Thou relationship. Both ways of naming are necessary to function in life, but the distinction Tournier is emphasizing is relevant for understanding anonymity. Being careful not to fall into the trap of conflating the name/symbol with the person/ reality both philosophically and textually, we can still observe the importance of naming and the implications of the removal of the name. Walker and Tournier have highlighted two essential realities that names and naming symbolize which are extremely pertinent to the discussion: affirmation and individuality of personhood. It will be shown that anonymity in Judges 19-21 relegates these realities to oblivion.

If one performs a cursory reading of the Hebrew Scriptures he or she readily observes the importance of names and naming. The reader of the Hebrew Bible initially encounters God creating order from chaos by the speaking and naming of his 'creative word' (Gen. 1). Next the reader observes the creator relegating this powerful act of naming to humankind (Gen. 2.19-20). Gen. 4.26 equates recognition and worship of YHWH with 'calling on the name of the Lord'. Immediately in chs. 4

18. M. Buber, I and Thou (trans. W. Kaufman; New York: Scribner's Sons, 1970).

19. The Naming of Persons, p. 3.

20. The Naming of Persons, p. 5. 
and 5 the reader confronts the first of many significant genealogies occurring in Genesis. In fact, Genesis contains one of the two largest sections of genealogies in the Hebrew Bible. Chronicles is the other book containing major sections of genealogical material. What is significant at this juncture is that the first book in the Hebrew canon contains major genealogies and the last book also does the same. ${ }^{21}$ Is it safe to say that names and lists of names form a loose type of inclusio for the Hebrew Bible?

Names and naming in the Hebrew Bible have a multitude of functions much too numerous to delineate in this treatise, so just a few of the more prominent will be noted. ${ }^{22}$ YHWH is known and worshipped by his name (Gen. 4.26); he refuses to give a true personal name (Exod. 3.14); Israel is commanded not to misuse his name, which implies misusing his person (Exod. 20.7); ${ }^{23}$ and he insists on remaining anonymous (Gen. 32.27-30; Judg. 13.17-18). Names are given by individuals or YHWH for the purpose of foreshadowing destinies (Jacob, Gen. 25.26) or circumstances (Esau, Gen. 25.25, and Ichabod, 1 Sam. 4.21). Many of the names communicate some form of meaning: Abimelech-'my father is king' (Judg. 9) and Moses-'drawn out' (Exod. 2.10). Names are changed to indicate different messages in the story, such as Abram/ Abraham (Gen. 17.5) and Jacob/Israel (Gen. 32.28). Though this is an extremely cursory representation of the data, once again it can be observed that the Hebrew narratives place great stress on names and the act of naming. ${ }^{24}$ Therefore, when the reader approaches an anonymous

21. "The Hebrew Bible contains two major hlocks of genealogical material, and within these two blocks most of the important genealogies are found. The first large collection of genealogical data appears in Genesis... The second large genealogical collection forms the introduction to the Chronicler's history (1 Chron. 1-9) and contains many of the genealogies found in Genesis, along with a great deal of additional genealogical information' (R.R. Wilson, Genealogy and History in the Biblical World [New Haven: Yale University Press, 1977], p. 137).

22. See J. Barr, 'The Symbolism of Names in the Old Testament', BJRL 52 (1969), pp. 11-21.

23. I am suggesting that though the name does not encompass the identity or essence of the named, the name in the Hebrew Bible was closely related to the personhood of the person. For example, if one misused the name of God one misused the person. The name represented something significant-the person.

24. 'Because the name is the expression of a person's essence in Hebrew thought, the destroying of one's name is synonymous with annihilation...' (B.S. Childs, Memory and Tradition in Israel [London: SCM Press, 1962], p. 71). 
character, or even an entire narrative with anonymous characters, he or she must be surprised to encounter such happenings in the text.

Surprisingly, however, anonymity occurs extensively throughout the fabula of Judges 19-21. Every character in Judges 19-21 remains anonymous with the exception of Phinehas (20.28), who ironically is more a name than an actant. The one named character in Judg. 19-21 is framed by nameless characters, whereas the first anonymous character in Judg. 1.1-3.6 (the builder of Luz-Judg. 1.23-26) is framed by an overabundance of named characters, tribes, naming and renaming. This strange lack of names and naming in chs. 19-21 is curious in light of the plethora of names (tribal and personal) in Joshua and the introduction to Judges. In addition, just as Judges ends with the absence of names, the first chapters of Samuel begin with the lineage of Elkanah ('there lived a certain man by the name of Elkanah the son of Jehoram, the son of Elihu, the son of Tohu, the son of Zuph, an Ephraimite'). ${ }^{25}$ Also, the fabula in the first chapters of Samuel is inundated with names (Elkanah, Peninnah, Hannah, Hophni, Phinehas, Eli and Samuel). Furthermore, every major and minor judge in the Judges narrative possesses a name, and, more so than not, the name expresses some further understanding of the different stories or introduces a subtle 'twist' to the story. Adonibezek means 'god of pebble'; Deborah-'bee'; Barak-'flash of lightning'; Gideon - 'hewer or hacker' ${ }^{26}$ and Abimelech - 'my father is king'. ${ }^{27}$ Two other remarkable comparisons of naming take place in the Gideon narrative. Gideon's 'insignificant' servant is named-'Purah' (7.10), and Gideon possesses two names (Jerubbaal) with each one contributing to the narrative. The significance of naming in the book of Judges is in marked contrast with the disappearance of the names of all

25. Ironically, the unnamed Levite devoid of a lineage in the narrative was also from the hill country of Ephraim. It is also interesting to note that the story begins in the place where Judges ended--Shiloh. See W.J. Dumbrell, “"In Those Days There was no King in Israel; Every Man Did What was Right in his own Eyes". The Purpose of the Book of Judges Reconsidered', JSOT 25 (1983), p. 24. 'So we may suspect that the concluding statement of the book (21.25) closes comment upon the dubious social character of Shiloh and yet serves to introduce further material which follows in 1 Samuel 1-3'.

26. Note Klein's discussion of the interplay between Gideon's two names and the presentation of the story (L.R. Klein, The Triumph of Irony in the Book of Judges [Sheffield: Almond Press, 1989], pp. 55-68).

27. Not all names in Judges have such relevance to their respective stories. Ehud, Achsah and Othniel contribute nothing to the reading of the stories. 
the major actants in the conclusion of Judges. While Gideon bears two names and his servant, who is completely irrelevant to the development of the story, is named, the entire cast of players in chs. 19-21 exists within the story nameless.

With such acts of naming surrounding the Judges 19-21 narrative, anonymity breaks upon the reader in a dramatic way. Just as the reader must exercise caution not to place named characters in rigid categories of classification, he or she should be careful not to place anonymous characters in similar rigid categories of anonymity. The representations of anonymous characters function within the fabula just as named characters function. There are at least five basic functions of anonymity in the Hebrew Bible: (1) anonymous characters may simply play a minor role in the fabula - And a certain man found him [Joseph], and behold, he was wandering in the field; and the man asked him, "What are you looking for?"' (Gen. 37.15); (2) anonymous characters focus or quicken the plot-'And the spies saw a man coming out of the city...So he showed them the entrance to the city...And the man went into the land of the Hittites...' (Judg. 1.24-26); (3) anonymous characters focus and highlight other characters - 'the unnamed servant' who, though a major character in the pericope, focuses upon Rebekah, Isaac and Abraham (Gen. 24); (4) anonymity 'universalizes' the characters and events of the narrative-'every man did right in his eyes' (Judg. 19-21); and (5) anonymity as a socio-linguistic phenomenon deconstructs naming; anonymity parallels the loss of identity and personhood (Judg. 19-21). These categories of anonymity interact and overlap with one another so that it could be feasible for one nameless character to represent all five aspects of anonymity.

I propose that the Judges 19-21 pericope utilizes the last two usages of anonymity. First, anonymity expresses the universality of 'every man doing what was right in his own eyes'. The Judges 17-21 narrative is framed by the refrain, 'In those days there was no king in Israel; every man did what was right in his own eyes' $(17.6 ; 21.25){ }^{28}$ The Levite, his concubine, his father-in-law, the servant, the old host, the men of Gibeah, the women and children of Benjamin, the daughters of Shiloh, and the men of leaderless Israel are nameless in this extensive story. What better way to portray that every Levite, every father-in-law, every

28. The phrase 'In those days there was no king in Israel' also occurs in 18.1 and 19.1. See S. Talmon, 'In Those Days There was no King in Israel', Immanuel 5 (1975), pp. 27-29. 
host, every single man within that society committed such barbaric atrocities 'from Dan to Beersheba' (20.1) than by allowing every perpetrator in the narrative to exist nameless?

Anonymity gives the implicit impression that every individual within Israel was dangerous because every individual was doing right in his or her own eyes. The rest of the Judges narrative plays out this irony between the 'one' and the 'whole nation', individuality and universality,

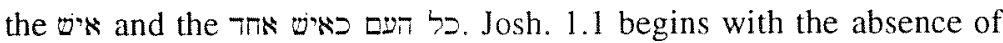
Moses and the leadership of Joshua. Judges in similar fashion commences with the death of the leader Joshua, but, unlike the Joshua narrative, there exists no leader to step into the void left by the man, Joshua. Instead, the 'sons of Israel' as a unified nation approach YHWH: 'Now it came about after the death of Joshua that the sons of Israel inquired of the Lord' (1.1). The plot line of Judges moves from the nation as a whole (1.1-3.6) back to the 'one' (the individual judges, 3.716.31 , and the characters in the conclusion, 17-21) to the nation as a whole: 'Then all the sons of Israel from Dan to Beersheba, including the land of Gilead, came out, and the congregation assembled as one man (כאיט אחד) to the Lord at Mizpah' (20.1). Ironically, the nation as 'one man' assembled together to dismember and disunite itself. Every person represented by the anonymous 'individual' - in the name of wholenesssought the unity of the nation by punishing Benjamin (ch. 20), which in this case was the virtual destruction of the nation and the individual. Anonymity as a literary device reflects the universality of violence and dismemberment.

The anonymous Levite, after leaving the anonymous host and the anonymous mob, dismembers the anonymous concubine. The dismemberment of the 'one' leads to the dismemberment of the nation as a whole, which was nearly the loss of Benjamin's name. ${ }^{29}$ In the schema that Judges in general and chs. 19-21 in particular offers, the 'one' $(1.1 \mathrm{a} / 19.1)$ leads to the 'all' $(1.1 \mathrm{~b} / 20.1,2,8,11)$ which leads to the 'no one' (21.6, 'One tribe is cut off from Israel today'). Anonymity expresses this narrative movement from the 'one' to the 'no one'.

Moreover, by viewing the anonymity of the concubine the reader gets the impression that 'every' concubine from Dan to Beersheba could be raped, murdered and dismembered. Anonymity portrayed a nation in

29. Note R. Girard's discussion of violence and the result of the loss of proper sacrifice within the community: Violence and the Sacred (trans. P. Gregory; Baltimore: Johns Hopkins University Press, 1977), pp. 39-67. 
which 'every' dispossessed would be victimized by the faceless, nameless perpetrators. Anonymity for the victim emphasized the loss of personhood. Anonymity interposed a powerful new dimension into the development of plot or characterization by abolishing a major element of human connectedness-named relating to named. Namelessness reflected in narrative terminology reflects the dehumanization of the victim. Anonymity infuses chaos and disorder. Not knowing the name and not being known by name dramatically influences behavior and relations. The assumption is that an individual with a name that is known would never do the same actions that an anonymous person would commit, or a person would relate differently to an individual who is named as opposed to an anonymous victim. For example, we should all be too familiar with the Nazis' gruesome practice of replacing the names of victims with numbers in the concentration camps-numbers are more easily disposed of than the named. Something about the anonymity of the victim removed the agents from the personhood of the victim.

Once again, the rape and disinheriting of the one concubine leads to the rape and disinheriting of the women and children of Benjamin (20.37-48) and the 'women of Shiloh' (21.19-24). By allowing the characters to remain anonymous, it is as if the narrator implicates not just one Levite, one city or one host, but the entire structure of that godless society. The anonymity of the characters assumes and characterizes the universality of the wickedness of the abusers and the dismemberment of the victims in that society. Anonymity disintegrates individuality to depict universal dismemberment. Epithet assumes community and universality but in reality eliminates individuality.

Secondly, anonymity is utilized in Judges 19-21 to deconstruct naming, meaning and identity. The shadowy world of Judges 19-21 was a world of alienation and annihilation. ${ }^{30}$ The narrative structure and characterization have gradually slipped into the ironic tragedy of the powerful abuser and the powerless victim. From the independent, powerful women in the beginning of the book (Achsah, Deborah) who participated in the division of the land and the protection of the tribes, the

30. 'The betrayal, rape, torture, murder, and dismemberment of an unnamed woman is a story we want to forget but are commanded to speak. It depicts the horrors of male power, brutality, and triumphalism; of female helplessness, abuse, and annihilation. To hear this story is to inhabit a world of unrelenting terror that refuses to let us pass by on the other side' (P. Trible, Texts of Terror [Philadelphia: Fortress Press, 1984], p. 65). 
narrative has spiralled down to portray nameless women who are divided by the tribes. From the one 'anonymous' character who is surrounded by the 'named' in the introduction ('and the spies saw a man coming out of the city', 1.24-26), the characterization shifts in chs. 19-21 to the one 'named' (20.28), surrounded and engulfed by the anonymous.

As mentioned previously, a labyrinth of names and naming encompasses Judges 19-21 and its anonymity. The anonymous concubine is not the first nameless victim, however, to experience the violence of this scattered nation. The point has been made that the book's structure moves along concomitantly with the abuse of the female characters. Mieke Bal is correct in maintaining that Judges concerns itself with the increasing disintegration of families and relationships, in particular the father-husband-daughter relationship.

Every actor or victim is known by familial, tribal or national epithets-not as individuals with personal identity. Epithets represent familial and societal relationships in the context of other characters (for example the concubine is known only in relation to her husband or father). Ironically, the use of epithets symbolizes the very problem of this society - the sacrifice of the individual for the sake of the community. ${ }^{31}$ The horrific dismemberment of the nameless concubine foreshadows and symbolizes Israel's dismemberment of itself. In 1 Sam. 11.6-7, Saul dismembered the oxen and dispatched the pieces to the twelve tribes with the message that the same dismembering would happen to any tribe that did not join the battle. In typical fashion for the book of Judges, no message is sent but the nation is dismembered in an absurd cycle of violence as a result of the sending.

Anonymity is the failure of the speech-act par excellence-the deliberate refusal to speak the name is to deny the person as subject and human. It is a failure of the 'creative word' that is so important in Genesis 1, where it signals a banishment of chaos into order. With the presence of the creative word comes order, relationship and identity. Without the creative word there is no possibility for an I-Thou relationship. Israel is on the precipice of internal, self-imposed exile and extinction which will lead to a loss of land and name. ${ }^{32}$ Anonymity

31. R. Girard, The Scapegoat (trans. Y. Frecero; Baltimore: Johns Hopkins University Press, 1986).

32. It is important to note the importance of the genealogies to the returning Israelites in Ezra-Nehemiah. See T. Cohn Eskenazi, In an Age of Prose: A Literary Approach to Ezra-Nehemiah (Atlanta: Scholars Press, 1988). 
symbolizes the loss of memory, which in turn then makes lineage and genealogy impossible. Strangely, in a myopic society in which there is an increasing loss of sight there is also a loss of names, which is a loss of faces, which is the loss of shame-- 'every man did right in his own eyes'.

The reader then is caught in the dilemma of attempting to understand the function of anonymity within this particular fabula (in a sense naming the anonymity) and allowing the anonymity to stand without marginalizing (agreeing with the narrator to annul the naming). Mieke Bal speaks of this dilemma of giving names to the anonymous women in Judges (Jephthah's daughter, Samson's bride, and the Levite's concubine).

To name this nameless character (Jephthah's daughter) is to violate the biblical text. Not to name her is to violate her with the text, endorsing the text's ideological position. I feel it is not only acceptable, but necessary, to take some critical distance from the alienating anonymity of the character without, however, losing sight of the structure of subjectivity that it signifies. Therefore, I will give this woman a name, but a name which stresses her independence. ${ }^{33}$

By naming the anonymous women of Judges, $\mathrm{Bal}$ is rightly asserting a feminist literary reading that gives prominence and subjectivity to these victims of a deteriorated society. In naming the anonymity she is attempting to deconstruct the dominant interpretations which ignore these nameless women.

I could not agree more wholeheartedly with the intended goal and results of her methodology. I do, however, take exception with one issue. If anonymity is contributing to the narrator's portrayal of a society that is quickly disintegrating because of its faithlessness to YHWH by exhibiting the marginalization and obliteration of the women's individuality, subjectivity and independence, then is it possible that naming is really a violation of the women and the concubine in particular? There is a violation in naming, in that as soon as these women are named the narrator's piquant exposé of such atrocities is enervated. The result would be the same as naming the 'unknown soldier'. As soon as he is named he loses his symbolization of all the nameless men and women whose sacrifice will never be known by name. Furthermore, we would be violating his real name identified with his 'real' identity. ${ }^{34}$

The problem $\mathrm{Bal}$ is noting is essential not only for a feminist

33. Death and Dissymmetry, p. 43.

34. See Trible's excellent discussion of the concubine, Texts of Terror, pp. 64-91. 
interpretation but for an interpretation that has any integrity whatsoever. This may be 'straining at an interpretative gnat'; however, in my opinion, existing with the anonymity of these women allows a pungent portrayal of what happens to the identity and personhood of women who exist or ironically do not exist in such a society. The nameless women will forever remain as poignant reminders of what happens to anonymous victims at the hands of anonymous perpetrators in a nameless, faceless society.

Anonymity also demands that the reader endure the ambivalence and 'uncomfortability' of the namelessness. Because anonymity resists interpretation, knowability and symbolization, the reader comes face-to-face with the 'uncanny'. The realm of the 'uncanny' is entered when textual realities such as anonymity are confronted 'which neither can be ignored nor named'. ${ }^{35}$ The reader of Judges, after being 'set up' by the initial stories, experiences increasing frustration as he or she views the gradual disintegration of the deuteronomistic paradigm, the events, the characters, and finally, the names and the naming. In Crossan's terms the conclusion of Judges (which possesses in a unique way the function of parable) disposes of the Joshua narrative. ${ }^{36}$ The reader is left with the destruction of everything established in the deuteronomic code and the exploits of Israel under the leadership of Joshua. He or she faces the dissolution of individual, family and society without the possibility of resolution.

According to Judg. 20.28 ('and Phinehas the son of Eleazar, Aaron's son, stood before it to minister in those days') the events of the conclusion occurred within one or two generations after the death of Joshua. This chronological, naming statement is strange indeed in light of the preceding Judges narrative. If the interpreter reads the book chronologically, it appears that the events of the conclusion transpired hundreds of years after Joshua's generation, when in reality the beginnings of the disintegration of Israel took place within a few years

35. Percy, 'Naming and Being', p. 154. 'In the everyday-world one is under the strongest compulsion to construe things one way or another - even things which are already known. Once Helen Keller knew what water was, she had to know what everything else was. After this total construction of one's world, it is only when something is radically different and resists interpretation in terms of the familiar symbols that one experiences "the uncanny"-that which is not yet known or symbolized' (p. 155).

36. J.D. Crossan, The Dark Interval (Sonoma, CA: Polebridge Press, 1988). pp. 47-69. 
after Joshua's death. Here, the narrator employed naming to establish a chronology that in turn deconstructs and inverts the coherence of Judges. The narrative tells us that the dehumanization of anonymity was one generation away from a leader and a nation who was faithful to YHWH. In this narrative conclusion, naming and anonymity come together in a bizarre fashion to frustrate and disrupt the reader. If we allow the text to speak, we find that it ushers us into the uncanny of the feminine while disrupting a masculine reading. In Judges 19-21, we are not allowed to name, nor are we allowed to resolve.

Ironically, however, there is a naming in the anonymity of Judges 1921. It is the naming of the results of the absence of God-the death of God within that society. With the absence of the Deity so comes the loss of identity. Human existence and identity are uniquely tied to the identity and existence of YHWH in this narrator's ideology.

It is in this anonymity, meaninglessness and dissolution that naming, meaning and resolution become possible. Out of the crucible of nonmeaning comes the impassioned desire for meaning; out of non-identity comes the hope for identity; out of anonymity comes the yearning for naming. 'Of this we can be certain: the forms of silence engage one another, and silence itself suddenly turns into speech' ${ }^{37}$ To represent the decomposing of a once faithful Israel which has constantly refused faithfulness to YHWH, the conclusion has brought the cycle of narrative to its nadir. The ambigious, absent, anonymous God led the Israelites to 'do what was right in their own eyes', and grotesque tragedy was the result. By ingenious design the reader is left with the ambivalence of anonymity but with the grand hope of resolution and identity-in other words, naming. The reader cannot depart the conclusion of Judges without an insatiable hunger for God or for a king who will one day do right in the eyes of YHWH. It is the king faithful to YHWH who will 'name' the widows, orphans and aliens.

Holy kings are greatly praised in Scripture because they restored the worship of God when it was corrupted or destroyed, or took care of religion that under them it might flourish pure and unblemished. But on the contrary, the Sacred History places anarchies among things evil: hecause there was no king in Israel, each man did as he pleased (Judg. 21.25). ${ }^{38}$

37. I. Hassan, The Dismemberment of Orpheus (Madison, WI: University of Wisconsin Press, 1982), p. 8.

38. John Calvin, Institutes of the Christian Religion (trans. F. Battles; Philadelphia: Westminster Press, 1960), p. 1495. 


\begin{abstract}
Recently, scholars such as Cheryl Exum and Mieke Bal have utilized a literary method for understanding the peculiar narrative technique of the Judges corpus. Exum explains that the narrator is utilizing the disintegration of his own plot to exhibit the dissolution of Israel's society, and Mieke Bal emphasizes the 'incoherence' of chronology as a means rather than an obstacle to understanding Judges. Moreover, I am suggesting that the narrator is applying disintegrating characterization to reflect a macabre society in which individuals dehumanize. This dehumanizing propelled the entire nation toward internal, self-imposed exile. Furthermore and more importantly, the narrator employs the concept of anonymity as a major literary technique to display both the universality of 'every one doing right in his own eyes' and the annihilation of the identity of the powerless individual which leads to the dismemberment of familial, tribal and national wholeness. Anonymity in Judg. 19-21 as a literary technique symbolizes and epitomizes the gradual, downward spiraling disintegration that is occurring increasingly throughout the narrative until the community faces radical anarchy in chs. 17-21.
\end{abstract}

